\title{
CONTROLLING HEALTH CARE COSTS THROUGH COMMERCIAL INSURANCE COMPANIES
}

Commercial insurance companies ${ }^{1}$ have the market incentives and the ability to take on a new role as controllers of rising health care costs. This Note will discuss the market for insurer-directed cost containment, the types of cost control alternatives that could be utilized and the legal restraints on insurer innovation. The analysis of the legal setting for insurer innovation in cost control includes an exploration of rules governing the corporate practice of medicine, the physician-patient relationship, Blue Shield laws, specific mandatory policy provisions and coverages, judicial extension of coverages, the effect of the Employee Retirement Income Security Act (ERISA) on employee health insurance plans, and antitrust implications of insurer innovation.

\section{The Market For Insurer-Sponsored Cost Containment}

\section{A. Historical Reluctance to Assume an Active Role.}

Consumers of health care, though increasingly concerned with rising costs, have not faced the fact that cost reduction requires a corresponding reduction in the resources that are expended by the health care industry. Two major factors have prevented consumers from confronting this elementary trade-off: the predominance of the third party payment system ${ }^{2}$ and an increasing level of consumer expectation in health care. ${ }^{3}$ The third party payment system has insulated the health care cost decisions of consumers, preventing them from recognizing the need to set utilization priorities. ${ }^{4}$ Consumers want their health services

1. This Note will not consider Blue Cross/Blue Shield plans, independent plans and the government as insurance providers. It will focus upon commercial health insurers, since they are private entities which currently provide financing as third party payors and should be influenced by the profit motive. Approximately one thousand commercial insurers write group and individual health insurance policies covering 115 million persons for hospital care in the United States. Subcomm. on Health of the House Comm. on Ways and Means, National Health InsurANCE RESOURCE BOOK 64-65 (1976).

2. Havighurst, Controlling Health Care Costs: Strengthening the Private Sector's Hand, $1 \mathrm{~J}$. Health Pol., Pol'y and L. 471, 474-75 (1977).

3. E. Burns, Health Services for Tomorrow-Trends and Issues 1-3 (1973).

4. The normal market forces have not been able to control costs in the health care sector because there is no party primarily interested in cost control. The provider of the services (supply) determines to a great extent which services the patient needs (demand); the provider is only 
to be provided at more reasonable rates, but at the same time they expect to fully benefit from all advances in health technology and to be given comprehensive treatment. ${ }^{5}$

As a result of these inconsistent demands, the desire for insurersponsored cost control may be outweighed by the expectation of comprehensive benefit packages, especially where the full cost consequences of the trade-off are not evident. Although increasing medical costs are reflected in the higher insurance premium for comprehensive coverages, the insurer is playing against a "stacked deck" in trying to market cost containment when someone other than the consumer bears most or all of the premium. ${ }^{6}$ The net evaluation of these incongruous consumer expectations has resulted in the reluctance of insurers to take the marketing risks associated with providing a product designed to satisfy untested consumer demands that appear contrary to known consumer desires.

Besides these inconsistent consumer demands, another influence that has lessened the attractiveness of cost containment by insurers is the structure of the tax laws. The tax treatment of health insurance premiums encourages employers and employees to use untaxed dollars to purchase group insurance having low deductibles. ${ }^{7}$ This accessible and inviting market for first dollar coverage has provided no real incentive to innovate with seemingly less attractive coverages.

minimally constrained by normal market pressures since the third party payor bears much of the cost of the purchase decision. The cost-reimbursement or cost-plus third party payment systems provide natural incentives for price escalation. The health care delivery and finance system has become structured with incentives that are insulated from, and often contrary to, those found in a competitive market. See McClure, The Medical Care System Under National Health Insurance: Four Models, 1 J. Health Pol., Pol'y and L. 22, 32-36 (1976); Inflation of Health Care Cosis: Hearings Before the Subcomm. on Health of the Senate Comm. on Labor and Public Welfare, 94th Cong., 2d Sess. 796 (1976) (statement of the Health Ins. Ass'n of America). The insured consumer is also not faced with the full costs of a medical care purchase decision; instead of balancing out-of-pocket costs against the benefits of health services, he is now faced with calculating how much his insurance will cover. Thus, insurance becomes an incentive to overutilize available health care services, resulting in a misallocation of resources in our economy and an artificially high equilibrium in the market for health care. See Havighurst \& Blumstein, Coping with Quality/Cost Trade-offs in Medical Care: The Role of PSROs, 70 Nw. U.L. Rev. 6, 9-20 (1975).

5. See Havighurst \& Blumstein, supra note 4, at 20-25; McClure, supra note 4, at 23. The combined effects of insurance and high consumer expectation compound the problem. An insured consumer is naturally influenced by the attitude that, having paid the cost of the insurance, he should receive the most benefit from it. This attitude is reinforced by and further reinforces the general public attitude that one should not try to economize when one's health is at stake and leads the insured consumer to demand the best possible health care available.

6. The predominance of standard health insurance coverages in many employee benefit packages may prevent employees from making any real cost/benefit decision.

7. Feldstein, How Tax Laws Fuel Hospital Costs, 3 Prism No. 12, at 15 (Jan. 1976); Havighurst, supra note 2, at $475-78$. 
Another factor that has deterred insurers from entering the market for cost containment is the hostility that such an entry is likely to elicit from the medical profession. The possibility of alienating the medical profession through insurer-inspired cost containment is far from imaginary. Outside interference can prompt responses from the medical profession that threaten the continued existence of the insurer as a business entity. ${ }^{8} \mathrm{~A}$ provider, because of his position in the health care delivery system, has more contact with the consumer-patient than the insurer does as third party payor. Thus, when the consumer of health services is faced with a conflict between his provider and his insurer, his resolution almost inevitably favors the provider. For example, if the insurance company has indicated that it ordinarily considers three $\mathrm{X}$-rays sufficient for diagnosing a particular problem but the patient's doctor recommends that six are necessary, the patient is most likely to take the doctor's advice. Only if the consumer decides that the benefits to him of remaining with his insurer are greater than or equal to the benefits of maintaining his relationship with his provider will there be any tendency to seek the services of another provider. ${ }^{9}$

Past insurer attempts to effect cost containment measures do not present a favorable prospect for the innovative insurer. The experience of hospital associations in Oregon during the first half of this century provides a valuable insight. ${ }^{10}$ These associations practiced contract medicine, providing comprehensive medical and hospital care in return for a fixed fee paid jointly by employer and employee. ${ }^{11}$ Even after gradually switching to payment on a fee-for-service basis, these associations were active in cost containment through such practices as requiring prior approval for surgery and reviewing medical fees. ${ }^{12}$

As providers developed an alternative method to finance these medical services via physician-controlled prepaid insurance plans, phy-

8. See text accompanying notes 10-17 infra.

9. In the case of an individual health policy, unless the monetary benefits are clearly evident and are sufficient to outweigh the value that the insured places on his relationship with his physician, the insurer is likely to lose a customer. In the case of a group health policy, the insurer stands in a slightly better position; it is the employer that will be choosing the insurer, a decision which the employee is more likely to accept, especially if the employer is paying all of the premium. However, in such a case the employer will likely consider the reactions of employees who might be faced with the prospect of changing physicians. Employee discontent will then weigh heavily in the employer's benefit analysis in choosing an insurer.

10. See Goldberg \& Greenberg, The Effect of Physician-Controlled Health Insurance: United States v. Oregon State Medical Society, 2 J. Health Pol., Pol'Y AND L. 48 (1977).

11. Id. 50. The similarity to prepaid group practice should be apparent. Hospital associations were organized for profit, providing strong incentive to control costs.

12. Id. 51,54. The monitoring of medical fees allowed the hospital associations to serve as informed buyers of medical care. Since they were organized for profit, the natural market incentive to control costs existed. 
sicians began refusing to deal directly with the hospital associations by not accepting direct payment. Instead they forced the associations to pay the patient who then shouldered the liability of the medical bill. ${ }^{13}$ This inconvenience, coupled with the attractive alternative of the physician-sponsored plans, caused many patients to change their financing system. Faced with this declining market, the hospital associations were forced to abandon their aggressive cost containment tactics and to assume the more passive role of merely a financing mechanism. ${ }^{14}$

A more recent example of the impact of threatened boycott is the attempt by Aetna Life and Casualty Company to enforce its rate schedule for medical services. The agreement with its policyholders stated "that where (1) Aetna disallowed a portion of the fee for exceeding prevailing limits, (2) attempts to resolve the difference with the doctor had failed, (3) the patient refuses to pay the balance himself, and (4) the doctor then sued him for it, Aetna would pay to defend the suit."15 When physicians became aware of this policy, they threatened a boycott. ${ }^{16}$ Again, the pressure of threatened boycott caused the innovative insurer to retreat from its cost control efforts. ${ }^{17}$

Sluggish acceptance by consumers and adverse reaction by the medical establishment have left insurers timid about innovation aimed at cost containment. Each insurer is cautious, not wanting to be the first in the pool after observing the chilling response its predecessors have received.

\section{B. The Incentives to Intervene.}

Because an insurance company's lower cost product would give it a competitive advantage over the higher priced conventional insurance coverages, an insurer stands to gain financially if its cost control efforts can be effectively marketed. Whether these cost containment efforts can be marketed profitably depends upon the consumer acceptance of less comprehensive insurance coverages. The possibility of successfully marketing a cost containment package has been enhanced by the pres-

13. Id. 58-62. The physician-sponsored plans not only offered the patient additional coverages not provided by hospital associations, but also did not disrupt the physician-patient relationship. The inherent attractiveness of the physician-sponsored plans was enhanced by the economic and noneconomic sanctions on noncooperating physicians that the plans provided. Physicians had "nothing to lose and everything to gain" by becoming members.

14. Id. 61 .

15. Rosenberg, He Challenged Aetna's Hard-line Fee Policy-and Won, MED. Econ., Sept. 11,1972 , at 31 .

16. Letters to the Editor, MED. ECON., Dec. 4, 1972, at 27-29.

17. Goldberg \& Greenberg, supra note 10, at 64-65. 
ent market environment. ${ }^{18}$ Inflation in health care costs has made it probable that the government will intervene if the private sector does not correct the problem itself. Further, the escalation in health care and insurance costs has caused increased awareness among consumers who are now demanding that some limits be placed on such escalation. Finally, the prevalence of employer-purchased insurance, which has traditionally insulated consumers from health care cost trade-offs, can now provide a market for cost-conscious coverages and be used to educate consumers on the advantages of cost containment.

Both the medical profession and the insurance industry may find themselves handcuffed by bureaucratic red tape and regulations if the government should further intervene in the health care sector. Physicians want neither the governmental control that would accompany national health insurance nor the problems encountered when working within government-sponsored programs. ${ }^{19}$ Private insurers are also wary of many of the proposals for national health insurance, not wanting to be omitted from any prospective scheme. ${ }^{20}$ If the government assumes the role of the financing mechanism in any program of national health insurance, commercial insurers may find themselves squeezed out of the market by their own inaction. ${ }^{21}$

The escalation in health care costs reflected in higher insurance costs has also made the soil more fertile for innovation. Consumers, seeing the increased size of their medical bills and feeling direct economic pressure when paying insurance premiums, are demanding that some controls be placed on such rampant inflation. This consumer demand for a new service, that of cost containment, provides a valuable opportunity for insurers. ${ }^{22}$ No longer should the insurers view the market as demanding an intermediary that only performs the financing function; the market now seeks an intermediary that also can provide

18. In assessing the changes in the market environment, an insurer will not have to risk all its resources to determine if a demand for such a plan exists. Business firms can effectively analyze the market reaction to new products by test marketing, which allows a firm to gain information from the "mini-market" reaction without having to risk additional resources of the business in a full-scale effort. See P. Kotler, Marketing Management 218-22 (3d ed. 1976).

19. See National Health Insurance 39 (T. Fain, K. Plant, R. Milloy eds. 1977).

20. Id. 50. See Inflation of Health Care Costs: Hearings, supra note 4; Hanson, The Private Insurance Industry and State Insurance Regulatory Activities as Alternatives to Federally Enacted Comprehensive National Health Insurance Legislation, 6 TOL. L. REv. 677 (1975).

21. The federal government has already entered the health insurance market through Medicare and Medicaid, and also provides financing in other insurance markets, such as crop insurance. The areas of government involvement are the result of the private insurers being unwilling to provide the needed financing.

22. The commercial insurer, still exposed to the marketplace incentives to control the cost of its product, appears to be the most likely party in the system to provide cost control services. 
the cost control function. Some large corporate consumers of insurance, dissatisfied with the cost control efforts of third party payors, have already implemented their own financing systems for health care costs, hoping to achieve more control over expenditures than that which is provided by insurers. ${ }^{23}$ While competition in the health insurance market has driven down the percentage of the premium that goes for administrative expenses, ${ }^{24}$ the inflationary spiral continues. ${ }^{25}$ Given that administrative costs are a mere fraction of the overall premium, ${ }^{26}$ insurer efforts need to be redirected at reducing the portion of the premium paid out in benefits. ${ }^{27}$ Tired of the financial strain caused by rising medical costs, the consumer will be more aware of the trade-offs that must be made with alternatives in health protection and will be more receptive to insurance plans that can meet his demand for cost containment.

Insurer involvement in curbing health care costs may also be sold to the public by working with those employers who are concerned about the rising health care costs of their employee benefit plans. ${ }^{28} \mathrm{Em}$ ployers not only share an interest in cost containment, but they are the prime and immediate consumers of the insurer's product. Working in the development of cost control plans, the insurer can create the market

23. See, e.g., the self-insurance plan of Goodyear, 41 Fed. Reg. 40,309 (1976).

24. The percentage of the insurance premium that is retained by the commercial insurer in group policies has decreased from $30 \%$ in 1950 to $10 \%$ in 1975 . Inflation of Health Care Costs: Hearings, supra note 4, at 796. Similar reductions can be found in individual policies, although a higher percentage of those premiums are used for administrative expenses since the efficiencies of handling group policies are not present. Since administrative costs constitute only a small part of the overall premium, efforts spent minimizing these costs will have little ultimate impact.

25. National Health INSURANCE, supra note 19, at 283-89.

26. See note 24 supra.

27. The high premium volume that occurs with conventional insurance coverages is one of the disincentives in the health care system that has discouraged cost control. See note 4 supra. The higher premiums associated with comprehensive coverage provide more revenue which the insurer can use to cover expenses and achieve profits. However, if the insurer reduces the total cost of its product, this could lead to an increase in its market share which in turn could help maintain a sufficient total premium volume despite a decrease in the premiums from individual policies. While the percentage of the policy premiums paid out in benefits would decrease and the percentage of policy premium needed for expenses would increase, such increases would be justified in light of the cost control service provided by the insurer.

28. Some employers may not be able to take advantage of insurer cost containment through modified benefit packages because of union demands that currently prevent reductions in fringe benefits. This should not, however, prevent concerned employers from evaluating alternative health care expense plans with unions; both sides should be concerned with avoiding health insurance plans that waste funds that might otherwise be used for wage increases or other employee benefits. Unions themselves have been active in sponsoring some cost containment measures. See, e.g., 41 Fed. Reg. 40,300-07, 40,315-23 (1976): United Storeworkers Union (prospective review of elective surgery); International Ladies Garment Workers Union (leverage through volume purchasing of prescription drugs); Amalgamated Clothing and Textile Workers Union (Health Management Organizations); United Mine Workers of America (claims review). 
for its product while the employer realizes monetary savings. Employee and union representatives must be included in the planning stages, both to educate them about the advantages of cost containment and to make the employer more receptive to such plans.

The educational process should not be halted at the managerial level. To make cost containment efforts successful, the individuals who are affected as patients in health care decisions should also understand the benefits of such plans. Employees should be made aware that successful cost containment efforts may result in such tangible benefits as higher wages. ${ }^{29}$ Consumers can be taught the importance of making individual cost/benefit trade-off decisions; restructuring the health care delivery and financing system to allow the reinstatement of individual decision making can be an important mechanism for aiding cost containment.

\section{Alternative Strategies for Cost Containment}

An evaluation of the means by which an insurer might take advantage of the market opportunity and help curb the costs of health care services reveals many alternative strategies that can avoid complete government intervention. Various parties in the delivery system can be responsible for cost containment. The range of possible delivery systems can be conceptualized as a continuum with the simple cash-forservice method of financing at one end and provider-sponsored prepayment plans at the other. At these two extremes health costs are optimally controlled, because at least one of the parties (either the cash paying patient or the provider) is directly involved in utilization decisions and has an interest in keeping costs down. ${ }^{30}$ Between these ex-

29. Any employer cutting back on health insurance coverages, even with the support of employee representatives, is very likely to have discontented employees due to the prevailing public attitude concerning health care. See notes 4-5 supra and text accompanying notes 3-5 supra. To help avoid this, an insurer could develop alternative group coverages, allowing the employee to choose between more health benefits with lower wages or less comprehensive health benefits with higher wages. Tax laws treat both employee benefits and wages as business deductions, I.R.C. § 162 , so the method of employee benefits should not affect the employer's decision. From the employee's standpoint, the additional wages would be included in gross income while the health insurance benefits that reimburse him for medical expenses may be excluded from gross income. I.R.C. § 105(b). The additional take home pay may still be enough to offset this drawback in the employee's decision even though under current tax laws he can obtain more coverage through his employer's plan than he can purchase with his after-tax pay. See text accompanying note 7 supra. An additional incentive for the employee to purchase his own insurance is found under I.R.C. § 104(a)(3), which excludes from gross income amounts received for personal injuries or sickness under policies that the individual himself has purchased. Note that this exclusion applies to all amounts, not just the amounts which reimburse the employee as under I.R.C. § 105.

30. A cash system most closely resembles a traditional market, where the consumer demand is a market force that controls the price of health care services. See McClure, supra note 4, at 40- 
tremes are other delivery systems, such as the closed-panel concept, ${ }^{31}$ Health Care Alliances (HCAs) ${ }^{32}$ and Individual Practice Associations (IPAs), ${ }^{33}$ through which an insurer can take a very active role in cost control.

Whatever strategy an insurer might decide to pursue, policy provisions are the major variables that the insurer can manipulate to achieve its aims. While an insurer can adopt various strategies to implement a cost control scheme, three basic approaches seem to be available: ${ }^{34}$ altering amounts and types of policy benefits; implementing utilization review mechanisms; and promoting variations in the financing and delivery systems. A successful plan will very likely combine more than one of these approaches while attempting to overcome some of the limitations of current practices aimed at cost containment.

The easiest policy provisions to alter are those defining policy benefits. The insured and insurer are basically free to bargain concerning the limitations on coverages; ${ }^{35}$ significant cost reductions would accrue through the use of higher deductibles, greater copayment percentages and less comprehensiveness in the range of services covered. ${ }^{36} \mathrm{~A}$ decrease in first dollar coverages would be particularly effective in reduc-

41. Placing the burden of cost control on the provider is also effective, because it eliminates unnecessary medical care. Note that under either alternative, the nonpaying party in the provider/consumer pairing will always have an incentive to spend, while the other (the paying party) will always have an incentive to reduce spending. The potential conflict that may result from the provider also performing the cost control function is open to criticism. While his professional judgment may encourage further expenditure for health care treatment, his economic motives may prevent such unrestrained professional judgment.

31. For a discussion of the closed panel and related legal issues, see Kallstrom, Health Care Cost Conirol By Third Party Payors: Fee Schedules and the Sherman Act, 1978 Duke L.J. 645.

32. For a discussion of the basic structure of the HCA, see Reynolds, $A$ New Scheme to Force You to Compete for Patients, MED. Econ., Mar. 21, 1977, at 23.

33. For a discussion of the Individual Practice Association, see Edgahl, Taft, Friedland \& Linde, The Potential of Organizations of Fee-for-service Physicians for Achieving Significant Decreases in Hospitalization, 186 ANNALS OF SURGerY No. 3, at 388 (Sept. 1977).

34. While these approaches are not mutually exclusive and are arbitrarily chosen to some extent, this framework can allow an insurer to better analyze prospective strategies. For suggestions as to specific strategies, see Havighurst, Professional Restraints on Innovation in Health Care Financing, 1978 DUKE L. J. 303, 321-26.

35. While the insurance contract is considered a contract of adhesion, the parties can choose the types of coverage, policy limits, deductible amounts and copayment percentages.

36. The deductible amount is the amount of expense which the insured incurs before his insurance begins to pay. Cost sharing by the insured also occurs through copayment provisions, under which the insurer and insured each pay a percentage of all expenses above the deductible amount. Copayment provisions help maintain some cost consciousness in the insured, though to a reduced extent. Under an 80-20 copayment scheme, the insured can receive a dollar's worth of health services for only 20 cents. See generally W. MEYER, Life AND HEALTH INSURANCE LAW \& 18.6 (1972). 
ing the costs of the policy. ${ }^{37}$ Cost sharing revives cost consciousness in the individual receiving medical treatment, since the individual is faced with the full cost of the medical care falling within the deductible amount. The types of health care services that are covered can also be manipulated. The clear trend has been to increase the kinds of medical treatment for which the policy will pay. ${ }^{38}$ The resulting "cumulative package," however, is one of the factors most responsible for the escalation of health care costs.

The coordination-of-benefits provision in many policies has been one successful measure designed to prevent an insured from being reimbursed more than once for medical expenses. ${ }^{39}$ Other measures, such as providing coverage for pre-admission testing and out-patient care, while designed to substitute less expensive forms of health care by avoiding hospitalization, have had questionable effects on cost containment. ${ }^{40}$ These coverage extensions may be ineffective as cost control measures unless accompanied by corresponding reductions in policy coverages or benefits. Each additional benefit paid by the third party removes one more marketplace decision from the consumer. Unchecked by market forces, the continuing rise in medical costs must be passed on in higher premiums. Limited coverage would reduce the cost of insurance while at the same time subjecting certain health care decisions to ordinary market forces.

Aside from altering amounts and types of coverages, a second approach is for the insurer to assume a more active role in monitoring utilization. With respect to cost control procedures, insurers have used variations of claims review to isolate cases of high fees. ${ }^{41}$ An inherent

37. See H. Diprete, Third Party Influences in Benefit Plan Design (June 3, 1977) (background paper for June 34, 1977 conference by Boston University Program on Public Policy for Quality Health Care) (describing various coverage plans yielding from 5\% to $50 \%$ premium reductions).

38. Policy coverage has expanded both by reducing the amount of cost sharing by the insured and by increasing the types of benefits provided, such as dental care, prescription drugs and psychological treatment.

39. See Berman v. Group Health Ass'n, 316 A.2d 863 (D.C. Cir.), cert. denied, 419 U.S. 842 (1974) (upholding the validity of a coordination-of-benefits provision in a group policy); W. MEYER, supra note 36, $\$ \$ 18.10-16$.

40. See A. Donabedian, Benefits in Medical Care Programs 148-200 (1976). Studies examining the effect of out-patient benefits and hospital use have been largely inconclusive. Some have reflected an overall increase in total charges, $i d$. 157, others have shown a savings in hospital use, id. 163, while still others have shown no significant relationship between the two, id. 164. A greater reduction in hospital use appears to be the result of a restructured delivery system accompanying the extended benefits, under which the physician is freed from many of the current incentives which promote hospital care. Id. 173. Where home care is also covered in the benefit package, a clear increase in overall cost has resulted. Id. 178-79.

41. C. Morrow, Health Care Guidance: Commercial Health Insurance and NaTIONAL POLICY 43-47 (1976). See text accompanying notes 10-17 supra. 
limitation of many forms of this approach is that after high fees have been isolated such cases are referred to review committees whose membership largely consists of other physicians. ${ }^{42}$ While members of the medical profession are the most qualified to evaluate the services performed by a fellow physician, there is serious doubt as to whether they are efficacious as cost watchdogs. ${ }^{43}$ Allowing reimbursement for second and third opinions prior to elective surgery is another coverage modification that promotes utilization review. ${ }^{44}$ This change has at least begun to curb the problem of unnecessary surgery and defensive medicine. However, unless as an enforcement mechanism a third opinion is made binding in cases of inconsistent prior opinions, many of the same incentives in the system remain to encourage the insured to proceed with the operation. ${ }^{45}$

The third area in which insurer innovations might occur involves the development of variations in the financing and delivery systems for health care services. Through policy coverages, insurers can also promote various delivery systems by requiring an insured to receive his medical services from a certain group of providers operating in a closed panel. ${ }^{46}$ Alternatively, plans can be structured using a fixed indemnity with the insurer designating physicians who will accept the insurer's reimbursement as full payment. This type of plan would still provide the insured with the option of choosing his own physician and paying out of his own pocket any difference in charges. A plan that provides a fixed indemnity for types of treatment regardless of the cost to the insured would encourage the insured to help control costs by finding the health care services he wants at lower costs, allowing the insured to retain any savings. ${ }^{47}$ Insurers have also been active in providing

42. Inflation of Health Care Costs: Hearings, supra note 4, at 798.

43. Some cost savings have occurred even with this system of control. Id. One may still question what additional savings might have been achieved if the interplay of market forces had been allowed to function originally through third party payors acting as informed buyers of the health care.

44. See National Health Insurance, Major Issues Vol. III: Hearings Before the Subcomm. on Health and the Environment of the House Comm. on Interstate and Foreign Commerce, 94th Cong., 2d Sess. 832 (1976) (statement of Robert Van Hoek, M.D.).

45. See text accompanying notes 2-5 supra.

46. For a discussion of the legality of the closed-panel system, see Kallstrom, supra note 31.

47. The tax implications of such a plan again tend to reduce the incentive to economize. Under employer-funded insurance, any excess of the fixed indemnity above the actual expenditure for health services by the insured must be reported as income of the insured, since these amounts are in excess of those needed to reimburse the insured for medical expenses which he has incurred. See I.R.C. § 105(b); Treas. Reg. § 1.105-2 (1956). An employer contributing to such a plan would still be allowed a business deduction under I.R.C. § 162(a). See [1978] 1 FED. TAX GuIDE (CCH) I 2171. Where the employee pays the policy premium, however, the above limitation does not apply. I.R.C. $\$ 104(a)(3)$. See note 29 supra. 
financial support for Health Maintenance Organizations (HMOs) and other delivery systems, thus even more directly subsidizing alternative methods of health care delivery. ${ }^{48}$

\section{Legal Obstacles to Insurer InNovations in Cost CONTROL ${ }^{49}$}

\section{A. Corporate Practice of Medicine and Interference with the Physician-Patient Relationship.}

One factor that must be considered in nearly any attempt by an insurer to contain costs is the general rule proscribing the practice of medicine in the corporate form. Any attempt by an insurer to employ a closed panel of physicians or to impose cost controls through second opinions is likely to be challenged under this doctrine. The rule is founded on the idea that acts of natural persons employed by the corporation are attributable to the "corporate person." poreal legal entity has "neither education, nor skill, nor ethics," the argument goes, the public should not be exposed to the dangers inherent in services provided by the corporation. ${ }^{51}$ While one of the major purposes of the concept was to protect the public from quackery, deception and commercial exploitation, another reason for its invocation has been to prevent lay interference with the physician-patient relationship. ${ }^{52}$

Two basic theories exist in which to couch the illegality of corporate practice. According to one theory, corporate practice is a violation of the medical licensing acts, the statutes that require a person to be licensed before practicing medicine. ${ }^{53}$ The other theory finds corporate practice a violation of public policy-an elastic rationale that can be stretched to include protection against the dangers of lay control over professional judgment, ${ }^{54}$ the commercial exploitation of medical prac-

48. Inflation of Health Care Costs: Hearings, supra note 4, at 799, 812, 823-27.

49. Different approaches to insurer innovation will encounter different legal challenges. Each state's laws must be analyzed for actual conflicts with the proposed activity by insurers. This section will attempt to identify and analyze some of the possible challenges common to various plans of cost containment.

50. 19 C.J.S. Corporations § 956 (1940).

51. State v. Bailey Dental Co., 211 Iowa 781, 785, 234 N.W. 260, 262 (1931).

52. Note, The Role of Prepaid Group Practice in Relieving the Medical Care Crisis, 84 HaRv. L. REv. 887, 961 (1971). For an excellent discussion of the history and implications of the corporate practice of medicine, see Willcox, Hospitals and the Corporate Practice of Medicine, 45 CorNELL L.Q. 432 (1960). See also Laufer, Ethical and Legal Restrictions on Contract and Corporate Practice of Medicine, 6 LAw \& CONTEMP. Prob. 516 (1939).

53. See People v. United Medical Serv., 362 Ill. 442, 200 N.E. 157 (1936).

54. See State Bd. of Medical Examiners v. Pacific Health Corp., 12 Cal. 2d 156, 82 P.2d 429 (1938), cert. denied, 306 U.S. 633 (1939). 
tice, ${ }^{55}$ a decrease in professional standards, ${ }^{56}$ and the division of the practitioner's loyalty between patient and profit-making employer. ${ }^{57}$ Each of these theories could present problems to market innovations.

One commentator, however, has concluded that an examination of the state medical licensing acts often reveals that corporations were not intended to be included as "persons" under these statutes and, hence, were not intended to be excluded from the practice of medicine. ${ }^{58}$ One must then turn to the judicially imposed public policy restraints that are designed for the protection of the public; the arguments raised in support of such restraints should be continually reevaluated to assure that the dangers which they seek to avoid are not imaginary.

If the rationales favoring the restraints are no longer as strong as those against them, the courts should not hesitate to remove these judicially erected barriers. Most of the public policy arguments against corporate practice are predicated on the notion that it would adversely affect the physician-patient relationship. ${ }^{59}$ This type of argument assumes that corporate practice will necessarily entail an employer-employee relationship between the doctor and the corporation and that such a relationship creates an inherent conflict of interest for the doctor. However, employer-employee relationships currently exist between corporations and licensed physicians that have not been found to constitute the corporate practice of medicine. ${ }^{60}$ Courts have been particularly flexible in finding an independent contractor relationship in cases involving nonprofit corporations, recognizing that the public policy considerations were not applicable. ${ }^{61} \mathrm{~A}$ different result, however, seems to be reached where profit-making entities are involved. ${ }^{62}$ In

55. See Parker v. Board of Dental Examiners, 216 Cal. 285, 14 P.2d 67 (1932).

56. See State v. Boren, 36 Wash. 2d 522, 219 P.2d 566 (1950).

57. See Silver v. Lansburgh \& Bros., 111 F.2d 518 (D.C. Cir. 1940).

58. Willcox, supra note 52 , at $437-42$.

59. The importance of this relationship has been explicitly recognized by the Supreme Court in Doe v. Bolton, 410 U.S. 179, 192 (1973); Roe v. Wade, 410 U.S. 113, 163 (1973); and United States v. Oregon State Medical Soc'y, 343 U.S. 326, 336 (1952).

60. Some of the numerous examples include hospital residents, radiologists, pathologists and salaried clinical physicians. Courts have at times applied a different standard as to what constitutes an employment relationship when dealing with the corporate practice rule than when dealing with other areas of the law. Willcox, supra note 52, at 450-53.

61. See, e.g., Group Health Ass'n v. Moor, 24 F. Supp. 445 (D.D.C. 1938), aff'd on other grounds sub nom. Jordan v. Group Health Ass'n, 107 F.2d 239 (D.C. Cir. 1939); Los Angeles County v. Ford, 121 Cal. App. 2d 407, 263 P.2d 638 (1953). In both cases the courts rejected charges of corporate practice, pointing out that the dangers of commercialization did not exist.

62. See, e.g., State Bd. of Medical Examiners v. Pacific Health Corp., 12 Cal. 2d 156, 82 P.2d 429 (1938), cert. denied, 306 U.S. 633 (1939); Pacific Employers Ins. Co. v. Carpenter, 10 Cal. App. 2d 592, 52 P.2d 992 (1935). 
State Board of Medical Examiners v. Pacific Health Corp. ${ }^{63}$ the defendant was a for-profit corporation that offered medical services to the public through a panel of physicians with whom it had contracted. Pacific Health Corporation, in turn, had contracted to provide medical services to members who had paid for this service. When a contract holder suffered injury or illness, the corporation directed the holder to a particular health-care provider. The physicians were neither salaried nor directed by the corporation, but were compensated according to actual services rendered. Despite what appeared to be an independent contractor relationship between the corporation and the physician, the majority of a divided California Supreme Court would not permit the "policy of the law [to] be circumvented by technical distinctions in the manner which the doctors are engaged, designated or compensated by the corporation." ${ }^{\prime 64}$ The per curiam opinion justified the holding on policy reasons:

The evils of divided loyalty and impaired confidence would seem to be equally present whether the doctor received benefits from the corporation in the form of salary or fees. And freedom of choice is destroyed, and the elements of solicitation of medical business and lay control of the profession are present whenever the corporation seeks such business from the general public and turns it over to a special group of doctors. ${ }^{65}$

Three justices strongly dissented, finding neither a violation of the medical practice statute nor the contravention of public policy. They found nothing to indicate that the corporation either directly or indirectly supervised the doctors in the professional services rendered to member-patients. ${ }^{66}$

The majority was also forced to account for the apparent legality of other corporations that furnish medical services. It distinguished such practice on the grounds that the services were provided to a particular association or group of employees, that they did not involve the solicitation of the public and that most cases involved nonprofit entities in which physicians were not exploited for the benefit of shareholders. ${ }^{67}$

The profit/nonprofit distinction is too imprecise a rule upon which to rest the future of corporate practice of medicine. ${ }^{68}$ The real issue is the degree to which a corporation interferes with the physician's profes-

63. 12 Cal. 2d 156, 82 P.2d 429 (1938), cert. denied, 306 U.S. 633 (1939).

64. 12 Cal. $2 \mathrm{~d}$ at $158,82 \mathrm{P} .2 \mathrm{~d}$ at 430 .

65. Id. at $158-59,82$ P.2d at 430 .

66. Id. at 163,82 P.2d at 432 .

67. Id. at $160,82 \mathrm{P} .2 \mathrm{~d}$ at 431 .

68. Note, supra note 52, at 962. Physicians themselves are not immune from the profit motive. See Havighurst, Health Maintenance Organizations and the Market for Health Services, 35 LAW \& CONTEMP. Prob. 716, 753 (1970); McClure, supra note 4, at 33. 
sional judgment. This should be a qualitative test, focusing upon the nature of the control rather than upon the number of interconnections existing between the corporation and the physician.

So long as unfettered professional judgment governs decisions on medical care, it should not matter that the care is delivered under the auspices of a corporation. ${ }^{69}$ It follows that if the duties performed by the corporate entity are administrative rather than diagnostic, the arrangement should not violate the policies prohibiting corporate practice. ${ }^{70}$ The "commercialization" sought to be avoided is the type that would have negative results on the physician-patient relationship. ${ }^{71}$ If the precautions built into a delivery system can prevent this adverse impact, no public policy rationale justifies a holding that an alternative mechanism for cost containment is illegal merely because it is sponsored by a corporation. ${ }^{72}$

Policy provisions which limit insurance coverage may also be challenged as interfering with the physician-patient relationship or as restricting the physician's right to practice medicine. Whether the coverage eliminates reimbursement for some types of health care services or requires the insured to receive treatment from specified providers, a consumer of health care or his provider may find some limitations on his health care decisions. A distinction, however, must be drawn between interfering with medical decisions and defining the

69. Note, supra note 52, at 962. But cf. Bartron v. Codington County, 68 S.D. 309, 2 N.W.2d 337 (1942) (holding that despite a lack of interference with the physician-patient relationship, to have a layman as a shareholder of a clinic was against public policy).

70. See State Electro-Medical Inst. v. State, 74 Neb. 40, 103 N.W. 1078, (1905), where the court distinguished between the functions a corporation may perform and those it may not:

It is impossible to conceive of an impersonal entity "judging the nature, character and symptoms of the disease," or "determining the proper remedy," or giving or prescribing the application of the remedy to the disease. Members of the corporation, or persons in its employ, might do these things, but the corporation itself is incapable to do them. The qualification of a medical practitioner is personal to himself. The intention of the law is that one who undertakes to judge the nature of a disease, or to determine the proper remedy therefor, or to apply the remedy, must have certain personal qualifications.... Making contracts is not practicing medicine. Collecting the compensation therefor is not practicing medicine .... No professional qualifications are requisite for doing these things.

Id. at 43,103 N.W. at 1079 .

71. It must be recognized, however, that the physician-patient relationship does not always refer to a relationship that is free from the effects of operating efficiencies. Some clinics and hospitals are designed to operate with the patient seeing a physician who is available at the time rather than developing an ongoing relationship with a single physician. The practical difference between this system and one operated by a corporation is slight.

72. For a discussion of benefits that might result from the corporate practice of medicine, see J. LaDou \& J. Likens, Medicine and Money: Physicians as Businessmen 129-43 (1977). For an examination of the potential benefits of for-profit corporate delivery systems, see The Case for For-Profit Health Maintenance Organizations, 15 STUDY ON LEGAL IsSUES IN THE REORG. OF HeAlTH CARE InSTITUTIONS (1972). 
extent of insurance coverage. ${ }^{73}$ The above illustrations are better characterized as limited insurance coverages that the insured has voluntarily accepted or as coverages that are preconditions to the insured's receiving reimbursement, rather than as interference by the insurer in the professional judgment of the provider.

\section{B. Blue Shield Laws.}

Blue Shield statutes ${ }^{74}$ present another impediment to insurer innovation. These statutory provisions normally mandate the domination of the structure or operation of nonprofit health service corporations by providers. ${ }^{75}$ They were supported by medical societies and were enacted to preserve physician control over the practice of medicine. ${ }^{76}$ Insurers contemplating alternative delivery systems, such as prepaid group practice, have been faced with the prospect of having to organize under the state's Blue Shield statute and, as a result, succumb to the control of the medical societies. Enforcement of these statutes, however, has not always been strict-health service plans have been able to operate by using legal fictions and liberal interpretations of the law, or even by disregarding the statutory language. ${ }^{77}$

Some relaxation of these restrictive laws has occurred due to the Health Maintenance Organization Act of $1973,{ }^{78}$ which preempts some restrictive state requirements if a prepaid group plan meets federal standards. HMO-enabling legislation in more than half of the states also has relaxed many of the prior restrictions. ${ }^{79}$ However, not all types of health service plans can be organized under these more liberal HMO statutes. One problem is that some states still prohibit the organization of the HMO as a for-profit corporation..$^{80}$ Those not qualifying are still faced with the restrictive provisions contained in the Blue Shield laws.

Medical society control of Blue Shield-type plans may also be constitutionally challenged by innovative insurers. ${ }^{81}$ Restrictive provisions in state law have twice been struck down by the New Jersey Supreme

73. See Havighurst, supra note 2 , at $496-97$ n.62.

74. See, e.g., MASs. ANN. LAws chs. 176A-176C (Law. Co-op 1977).

75. Hansen, Laws Affecting Group Health Plans, 35 IowA L. REv. 209, 222-28 (1950).

76. Id: 225; Note, supra note 52, at 963. For a recent case challenging such a statute, see Garcia v. Texas State Bd. of Medical Examiners, 384 F. Supp. 434 (W.D. Tex. 1974).

77. Note, supra note 52, at 964-69.

78. 42 U.S.C. $\S 300$ e (Supp. V 1975), as amended by Pub. L. No. $94-460,90$ Stat. 1945 (1976).

79. J. LADOU \& J. LiKENS, supra note 72 , at 137-39.

80. Id.

81. See Comment, Prepayment Health Care Plan Enabling Acts-Are Their Restrictive Features Constitutional?, 7 DUQuESNE L. REv. 125 (1968). 
Court. ${ }^{82}$ One provision of the law required medical society approval of every director or trustee of the plan; another required the majority of the eligible physicians within a county to belong to the plan at all times before the plan could operate in the county. The court held that when, as under Blue Shield statutes, an interested private body is given the power to regulate the economic posture of another without sufficient standards or safeguards, the statute is an unlawful delegation of authority to a private group and a violation of due process. ${ }^{83}$

\section{Mandatory Policy Provisions and Coverages.}

Insurers may attempt to inject cost consciousness into the health care market by making alterations in the insurance policy itself, such as raising deductibles, requiring heavier cost sharing by the insured through higher copayment provisions, excluding certain medical treatments, mandating the use of more nonprofessionals to provide services and requiring greater use of ambulatory care. These types of changes, however, may be barred by mandatory policy provisions in both individual and group policies. ${ }^{84}$

The "payment of claims" provision is one example. It deals with the method through which an insurer may discharge its liability under the insurance contract. Part of this provision, mandatory in some states $^{85}$ and optional in others, ${ }^{86}$ deals with the question of to whom payment can be made:

[A]ll or a portion of any indemnities provided by this policy on account of hospital, nursing, medical or surgical services may, at the insurer's option . . . be paid directly to the hospital or person rendering such services; but it is not required that the services be rendered by a particular hospital or person. ${ }^{87}$

Similarly, some state statutes require the same type of provision in group health insurance policies, making the last clause even more ex-

82. Group Health Ins. of N.J. v. Howell, 43 N.J. 104, 202 A.2d 689 (1964); Group Health Ins. of N.J. v. Howell, 40 N.J. 436, 193 A.2d 103 (1963).

83. One ground for holding these provisions unconstitutional was that they were unreasonable and arbitrary. This type of substantive due process review is unlikely to be successful except in courts that have demonstrated a high degree of judicial activism. Comment, supra note 81, at 136. A more direct and decisive approach involves lobbying in the legislature to amend the restrictive provisions. Note, supra note 52, at 967-68.

84. More flexibility in mandatory provisions is found in group policies in order to adequately tailor the coverage to meet the needs of the group. One reason for fewer restraints in group plans is that normally an informed buyer is negotiating the contract for the group, needing less protection than an uninformed individual purchaser.

85. See, eg., Cal. Ins. Code \& 10350.9 (West 1972).

86. See, e.g., IND. Code ANN. \& 27-8-5-3(a)(9) (Burns 1975).

87. Id. (emphasis added). 
plicit: "but the policy may not require that the service be rendered by a particular hospital or person." 88 These statutory directives may present obstacles to an insurer attempting to contain costs by using a closed panel of physicians.

In a case involving this statutory construction, the court, in holding that an insurance policy did not provide coverage for medical care rendered by a podiatrist, stated in dicta that the wording of the statute was

statutory language of differentiation, by which policy designs that would permit the insurer to direct the destiny of the cure through the specific designation of the person or facilities, are prohibited. . . . Therefore, [the statutes] serve to prohibit this selective and discretionary designation of personnel for the treatment of the ill, rather than to affirmatively require insurers to indemnify for all attempted cures which are legally rendered. ${ }^{89}$

While this statutory language would not allow the insurer to require its insured to see a specific physician or be admitted at a specific facility, the court's holding implies that the insurer may exclude some medical care providers from its coverages. Such a holding is consistent with the concept that the insured must comply with the conditions precedent before collecting under the policy, one of which is receiving treatment from a "covered" physician. It must be noted, however, that in this case the distinction relied upon by the insurer resulted in denying reimbursement for services performed by a limited practice physician, ${ }^{90}$ a podiatrist, while allowing reimbursement for services performed by a physician licensed to practice general medicine. A more difficult case, with possibly a different result in light of the court's dicta, is one in which the insurer would deny reimbursement for treatment by some physicians while providing reimbursement for treatment by physicians of the same class. However, so long as the insured is not precluded from some freedom in the choice of his physician, the contractual agreement between the insurer and insured should not be read to violate statutory requirements. From another perspective, since these statutory provisions deal only with direct payment by the insurer to the provider, they would not appear to affect situations in which the insurer provides reimbursement or indemnity to the insured himself, since the

88. IND. CODE ANN. \& 27-8-5-10(c) (Burns 1975) (emphasis added).

89. Insurance Comm'rs of Ind. v. Mutual Medical Ins., Inc., 251 Ind. 296, 303-04, 241 N.E.2d 56, 61 (1968).

90. Some states now require reimbursement for limited practice physicians when they perform services that would normally be covered by the insurance contract. See N.Y. INs. LAW \& 221(5) (McKinney Supp. 1976). 
insured maintains freedom in choosing his own physician. ${ }^{91}$

In some states legal restraints prevent the insurer from limiting the extent and types of coverages. Some of the greatest restrictions on this type of insurer innovation exist in New York. There, all individual policies must provide minimum benefits for hospital room and board expenses, miscellaneous hospital expenses and surgical expenses. ${ }^{92}$ In an attempt to help contain costs, the legislature has also required that the individual health insurance policies that provide in-patient hospital benefits also provide coverage for out-patient benefits, emergency care, pre-admission testing, second surgical opinions, qualified home care and nursing home care. ${ }^{93}$ Both individual and group policies also require that the insurer reimburse the insured for certain treatments rendered by qualified practitioners other than physicians. ${ }^{94}$ While most of these measures are designed to avoid the high cost of hospital and overqualified professional care whenever possible, the impact of this type of control has not always achieved the envisioned cost reductions. ${ }^{95}$

The legislative efforts to protect the consumer who receives these new coverages also can have counterproductive effects on cost containment. These attempts often work to freeze part of the underlying status quo and thus handcuff insurer innovation. An example is again provided by New York's statute, which, while requiring coverage for less costly home health care, prohibits coverage that contains more than a fifty dollar deductible or lower than a seventy-five percent copayment provision. ${ }^{96}$ By mandating additional types of minimum coverages, the net effect of these statutes is to compound statutorily the cumulative insurance package.

The Model Comprehensive Health Insurance and Health Care Cost Containment Act includes some provisions that can aid in curbing health care costs. ${ }^{97}$ Under the Model Act, every insurance carrier would be required to affirmatively offer qualified comprehensive health insurance, even though the purchaser still has the option of purchasing less comprehensive coverages. Under either of the alternative deducti-

91. See note 47 supra and accompanying text.

92. N.Y. INS. LAw § 164(2)(B)(3) (McKinney Supp. 1976). See also NAIC Model INDIVIDual Accident and Sickness Minimum Standards Act, [1974] 1 Proceedings of the NaIC 414.

93. N.Y. INS. LAW § 164(7-c)-(7-j) (McKinney Supp. 1976).

94. N.Y. INS. LAw \& 164(7-a)-(7-d) (McKinney 1966 \& Supp. 1976), § 221(5)(b)-(e) (McKinney Supp. 1976).

95. See note 40 supra and accompanying text.

96. N.Y. INS. LAw \& 164(7-f) (McKinney Supp. 1976).

97. NaIC Model Comprehensive Health Insurance and Health Care Cost ConTAINMENT ACt, [1976] 2 PROCEedings of the NAIC 407. 
ble and copayment provisions of the Model Act, a two hundred dollar minimum deductible per person per policy year, as well as a twenty percent copayment provision for expenses above the deductible, must be imposed for each of these policies. ${ }^{98}$ The Act would also require insurers that provide coverage for expenses that would normally fall within the deductible, copayment or exclusion provisions to issue a "separate policy or endorsement containing a clear and separate disclosure of the total amount of premium required to insure the specified deductible, copayments or exclusions." "99 This requirement would better allow the insurance purchaser to weigh the marginal benefits of this first dollar coverage while still allowing free choice in the selection of these coverages.

\section{Judicial Extension of Policy Coverages.}

Coverage limitations and modifications must also overcome the obstacles of judicial interpretation that might attempt either to expand policy coverages or strike down policy provisions as unconscionable. Unequal bargaining power between the insurance company and the insured has led many courts to extend the rights of policyholders beyond those found in policy provisions. ${ }^{100}$ This is partly because an insurance contract is usually one of adhesion; consequently, any provision will be construed strictly against the insurer that drafted and issued it. ${ }^{101}$ Some decisions, moreover, have extended coverages beyond that allowed by any ambiguity in the policy language to provide benefits that the insured reasonably expected. ${ }^{102}$ One rationale for such extensions is that the insurance policy is complex and not understandable to the layman without extensive study. It may be possible, however, for the insurer to avoid the problem of these "reasonable expectations" by giving the insured notice of any change in policy coverages. ${ }^{103}$

Even if the insured is aware of policy limitations when contracting for coverage, a court may disallow the literal enforcement of these limitations if it considers them to be unconscionable. This usually occurs in

98. Id. $\S 6(C)$, Alternatives I \& II (amended at [1977] 1 Proceedings of THE NAIC 43-44).

99. NaIC Model Comprehensive Health Insurance and Health Care Cost Containment ACT \& 6(C)(4), [1977] 1 Proceedings of the NAIC 44.

100. See Keeton, Insurance Law Rights at Variance with Policy Provisions, 83 HARv. L. Rev. 961 (1970).

101. W. MEYER, supra note $36, \S 2.5$. The characteristics of contracts of adhesion, where the contract is presented to the applicant who has limited ability to negotiate its terms, are less likely to be found in larger group policies, where much negotiation occurs between the parties. Id. \& 2.3.

102. Keeton, supra note 100 , at $966-74$.

103. See Fassio v. Montana Physicians' Service, 553 P.2d 998 (Mont. 1976); Poch v. Equitable Life Assurance Soc'y, 343 Pa. 119, 22 A.2d 590 (1941). 
cases where enforcement of a policy provision would defeat the reasonable expectations of the great majority of policyholders who are not aware of the limitation or where restrictive definitions would not provide any coverage except in the extreme cases where the literal terms of the policy are met. ${ }^{104}$ Where an insurer takes precautions to avoid such a misunderstanding by fully explaining the extent and operation of coverages to its insureds, limitations on coverages should be upheld and the plain language of the policy effectuated unless such limitations are unconscionable, illegal or against public policy. ${ }^{105}$ Similarly, provisions in contracts between employers and an insurer should also withstand challenge by the insured employees. The California Supreme Court, for example, has sustained the validity of a provision in a medical services contract requiring arbitration of any malpractice claim by the state's employees. ${ }^{106}$

\section{E. ERISA Preemption of State Laws.}

As one examines the state laws which may restrict an insurer's efforts to contain costs, the implications of the Employee Retirement Income Security Act of 1974 (ERISA) ${ }^{107}$ come into question. Some state laws governing medical benefits provided by employers for their employees have been preempted by this Act. Under ERISA, an "employee welfare benefit plan" is defined as

any plan, fund, or program which was heretofore or is hereafter established or maintained by an employer or by an employee organization, or by both, to the extent that such plan, fund, or program was established or is maintained for the purpose of providing for its participants or their beneficiaries, through the purchase of insurance or otherwise, . . . medical, surgical, or hospital care or benefits . . . . .108

Although the Act directly regulates only reporting, disclosure and

104. Keeton, supra note 100 , at $974-77$.

105. See National Hills Shopping Center, Inc. v. Liberty Mut. Ins. Co., 551 F.2d 655 (5th Cir. 1977); Electron Mach. Corp. v. American Mercury Ins. Co., 297 F.2d 212 (5th Cir. 1961); Waterman S.S. Corp. v. Snow, 222 F. Supp. 892 (D. Or.), affd sub nom. General Accident Fire \& Life Assurance Corp. v. Snow, 331 F.2d 852 (9th Cir. 1963). On the issue of unconscionability in limiting coverages, a useful comparison can be made with proposals for no fault liability via contract in malpractice and other areas. See O'Connell, No Fault Liability by Contract for Doctors, Manufacturers, Retailers and Others, 632 INs. L.J. 531 (1975); O'Connell, An Elective No-Fault Liability Statute, 628 INS. L.J. 261 (1975). If legal challenges to elective no fault are to be resisted, the party relieved of the liability must provide the other party with reasonable compensation. See Havighurst, "Medical Adversity Insurance"-Has Its Time Come?, 1975 DuKE L.J. 1233, 1276-77. Similarly, the insurer can offer the insured reduced rates to justify reduced coverages. (1976).

106. Madden v. Kaiser Foundation Hosps., 17 Cal. 3d 699, 552 P.2d 1178, 131 Cal. Rptr. 882

107. 29 U.S.C. $\S \S 1001-1381$ (Supp. V 1975).

108. 29 U.S.C. \& 1002(1) (Supp. V 1975). 
fiduciary duties with respect to employee welfare benefit plans, ${ }^{109}$ it also summarily preempts all state regulation of ERISA-covered employee benefit plans. ${ }^{110}$ State laws regulating insurance are not subject to ERISA preemption;"11 however, Congress specifically forbade classification of employee benefit plans as "insurance companies" and thus made the plans subject to ERISA. ${ }^{12}$

The absolute preemption of state laws regulating such employee benefit plans may leave the courts to develop a federal common law in the unregulated areas according to the underlying principles of ERISA. ${ }^{13}$ At least one court, however, has held that since the substantive provisions of ERISA relating to health and accident insurance are the reporting and disclosure requirements, the substance of insurance plans that employers offer employees is not governed by ERISA. ${ }^{114}$

\section{F. Antitrust Implications.}

In evaluating possible market strategies for providing cost containments, insurers must be aware of the antitrust restraints that may be involved. While the McCarran Act specifically exempts the "business of insurance" from federal antitrust laws to the extent that state laws regulate such activities, ${ }^{115}$ legal questions arise as to which insurer ac-

109. 29 U.S.C. $\S \S 1021,1101$ (Supp. V 1975); Hewlett-Packard Co. v. Barnes, 425 F. Supp. 1294 (N.D. Cal. 1977), affd, 571 F.2d 502 (9th Cir. 1978); Insurers' Action Council, Inc. v. Heaton, 423 F. Supp. 921 (D. Minn. 1976).

110. Wayne Chemical, Inc. v. Columbus Agency Service Corp., 426 F. Supp. 316 (N.D. Ind.), modified on other grounds, 567 F.2d 692 (7th Cir. 1977); Hewlett Packard Co. v. Barnes, 425 F. Supp. 1294 (N.D. Cal. 1977), affd, 571 F.2d 502 (9th Cir. 1978); Azzaro v. Harnett, 414 F. Supp. 473 (S.D.N.Y. 1976), affd, 553 F.2d 93 (2d Cir.), cert. denied, 434 U.S. 824 (1977).

111. 29 U.S.C. \& 1144(b)(2)(A) (Supp. V 1975).

112. 29 U.S.C. \& 1144(b)(2)(B) (Supp. V 1975). The effect of this preemption may be to remove some restrictive state laws as obstacles to insurer innovation. But see notes 113-14 infra and accompanying text.

113. See Wayne Chemical, Inc. v. Columbus Agency Serv. Corp., 426 F. Supp. 316 (N.D. Ind. 1977). The court held that state law, even though preempted by ERISA, could be utilized when compatible with the federal law and could be adopted as the federal rule of decision. The case dealt with the convertibility provision of an insurance policy, an area not directly covered by the substantive provisions of ERISA. Id.

114. Insurers' Action Council, Inc. v. Heaton, 423 F. Supp. 921,926 (D. Minn. 1976). See also Hamberlin v. VIP Ins. Trust, 434 F. Supp. 1196 (D. Ariz. 1977). In its opinion, the Hamberlin court, faced with the question of whether a trust established by entrepreneurs for the purpose of marketing insurance products and services was subject to ERISA rather than state insurance regulation, stated: "They [the plans under consideration by the court] are no more ERISA plans than is any other insurance policy sold to an employee benefit plan." Id. at 1199 (quoting House CoMm. on EDUC. AND LABOR, Activity REPORT, H.R. REP. No. 94-1785, 94th Cong., 2d Sess. 48 (1977)) (emphasis added by court). This interpretation means that while ERISA does not add obstacles to an insurer's ability to vary coverages, it is unlikely to remove any state regulations on coverages.

115. 15 U.S.C. $§ 1012$ (1976). 
tivities are exempt. ${ }^{116}$ By means of an exception to this exemption, the Sherman Act is specifically made applicable to attempts of boycott, coercion or intimidation by insurers. ${ }^{17}$ If an insurer's cost containment activities fall within the protection of the McCarran Act, no Sherman Act sanctions can be invoked. However, these activities still would remain subject to state unfair competitive practices statutes, which often closely parallel or are even more extensive than their federal counterparts. ${ }^{118}$

Should an insurer find itself outside the exemption of the McCarran Act, this does not mean that the insurer's cost containment practices automatically fall within the proscriptions of the antitrust laws. Where sufficient competition exists in the insurance market, an insurer can act individually to implement cost control measures without fearing antitrust problems. An insurer that is able to gain a competitive advantage by meeting a market demand better than competitors is only reaping the fruits of the competition that antitrust is designed to protect. ${ }^{119}$

Collective action by insurers presents a more difficult analysis, but not one that warrants automatic antitrust condemnation. Some areas of insurer cooperation are allowed so long as they do not pose restraints on competition. For example, the exchange of cost and price information involved in rate making may, in a competitive market, be viewed as a means of fostering, rather than suppressing, competition and may therefore be in the public interest. ${ }^{120}$ Whether viewed as data dissemination activity by a trade association ${ }^{121}$ or as a joint venture, ${ }^{122}$ insurer cooperation in certain areas could be structured so that it would not

116. Any analysis of the scope of the McCarran Act exemption revolves around three basic issues: whether the innovation is part of the "business of insurance"; whether the state has a sufficient framework for regulating such activity and what the effects of its regulation will be; and whether the innovation involves a boycott, coercion or intimidation. See Kallstrom, supra note 31, at 684-89 and Weller, The McCarran-Ferguson Act's Antitust Exemption for Insurance: Language, History and Policy, 1978 DUKe L.J. 587 for a discussion of these issues.

117. 15 U.S.C. $\$ 1013$ (b) (1976).

118. See, e.g., ILL. ANN. STAT. ch. 73, § 1032 (Smith-Hurd Supp. 1978).

119. The possible opportunity to enjoy a superior market position is the driving force behind product innovation. Absent monopoly power and an intent to monopolize, an insurer's activities should not be found illegal. Such activities would not constitute "the willful acquisition or maintenance of that [monopoly] power as distinguished from growth or development as a consequence of a superior product, business acumen, or historical accident." United States v. Grinell Corp., 384 U.S. 563, 570-71 (1966).

120. Maple Flooring Mfr. Ass'n v. United States, 268 U.S. 563, 582-83 (1925). For guidelines of the conditions favorable to an exchange of information with minimal antitrust risks, see U.S. Dep't of Justice, The Pricing and Marketing of Insurance 116 (1977).

121. See generally U.S. DEP'T OF JUSTICE, supra note 120, at $99-118$.

122. Id. 119-45. 
violate federal antitrust laws. A different result, however, occurs where insurers agree to fix premium levels in their own market. ${ }^{123}$ Problems also may arise where such collective action by insurers gives them monopsony power in purchasing medical services from providers. ${ }^{124}$

The actual methods that insurers use to implement cost containment strategies must also be examined for possible antitrust violations. Where price fixing is not directed toward the insurer's own market, but toward the health care market, antitrust problems may be avoided under the ancillary restraint doctrine. ${ }^{125}$ An insurer may need to protect its use of a provider reimbursement schedule from the price fixing contamination that might occur where providers have collectively agreed to the rates of reimbursement that the schedule contains. ${ }^{126}$ Some type of provider panel arrangement may be a necessary condition of insurance coverage for an insurer to effectively control both utilization and cost. The antitrust difficulties in the panel approach do not appear to be as much of a legal obstacle as the corporate practice of medicine or Blue Shield laws. ${ }^{127}$ An insurer may even be able to avoid any problems involving discriminatory treatment of providers by utilizing policy provisions that allow free choice of physicians but contain incentives for the insured to utilize insurer-sponsored panels. ${ }^{128} \mathrm{As}$ insurers investigate alternative courses for effectuating their cost containment strategies, careful planning can prevent violations of both state and federal statutes aimed at preventing anticompetitive activities.

\section{ConClusion}

Although commercial insurers have traditionally not assumed an active role in controlling costs of health care services, current conditions in the market environment make it prudent for insurers to reevaluate their position. Extreme inflation in the health care sector has increased consumer awareness and demand for cost containment, making it probable that the government will intervene if the private sector does not furnish relief. The prevalence of employer-purchased

123. Cooperation by commercial insurers is likely to be viewed as anticompetitive activity, and if the combination is found either directly or indirectly to result in price fixing, such cooperation may be considered illegal per se under the Sherman Act. Id. 91-97. Since the collective price setting by insurers might be enforced by collective refusals to deal with noncooperative providers and because states do not actively regulate health insurance rates, the McCarran exemption would probably not apply.

124. Havighurst, supra note 34 , at 328-34.

125. Kallstrom, supra note 31 , at $659-65$.

126. Id. 678-84.

127. See text accompanying notes 50-83 supra.

128. See Havighurst, supra note 34, at 330-31. This may also avoid problems with some mandatory policy provisions. See text accompanying note 91 supra. 
insurance will provide an initial market through which the benefits of cost containment efforts may be realized.

By manipulating policy coverages, an insurer can promote innovative delivery systems, the implementation of cost controls on existing health services and renewed cost consciousness in the consumer of medical services. While some of these methods are currently being utilized, further innovations can provide a more effective curb on rising health care costs.

Legal challenges will be raised against the innovative insurer who assumes an active role in cost containment. One challenge facing many cost control strategies is the rule against corporate practice of medicine. So long as the insurer does not actively interfere with the physician's professional judgment, however, this rule should no longer be a barrier to the implementation of insurer-sponsored measures aimed at cost reduction. Blue Shield laws may pose a problem in some states, but their restrictive provisions can often be avoided through liberal enforcement and interpretation, federal preemption, or constitutional challenges. Mandatory policy provisions and coverages do present restraints on some types of insurer innovation, but many cost containment packages may be designed to avoid any conflict with these state laws.

Besides structuring coverages to bypass statutory restrictions, the insurer should also avoid policy provisions that courts will strike down as unconscionable or that may not be construed literally. If adequate precautions are taken by the insurer, the basic principles of contract law should uphold coverage limitations. The effects of ERISA on insurer cost containment efforts will probably not pose any greater restrictions than those which exist under state law. Although antitrust implications must also be considered for any cooperative cost containment efforts between insurers, an individual insurer's action that results in cost controls in the medical industry should not violate antitrust principles.

A valuable market opportunity awaits the innovative insurer who can effectively combine the financing function with the cost containment function in the health care sector. Legal restraints normally can be circumvented or overcome, and careful leadership, planning and cooperation among employers, labor, providers and insurers can pave the way to avoid adverse market reaction. ${ }^{129}$ In any dynamic market envi-

129. Leadership and cooperation among employers, labor, providers and insurers have been key factors in the success of the Twin-Cities Healthcare Development Project in Minneapolis. Inflation of Health Care Costs: Hearings, supra note 4, at 790-91. 
ronment, a stagnant firm dies; an adaptive firm survives; an innovative firm prospers. 